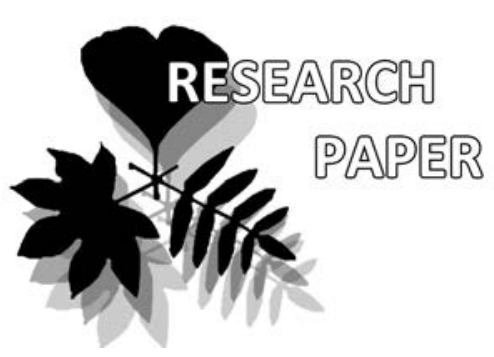

\title{
Nymphoides peltata (S.G. Gmel.) 0 . Kunze at the northern limit: ecophysiological peculiarities
}

\author{
Evgeniya F. Markovskaya ${ }^{1 *}$, Elena V. Novichonok ${ }^{2}$, \\ Tamara Yu. Dyachkova ${ }^{1} \&$ Kira V. Morozova ${ }^{1}$
}

\author{
Evgeniya F. Markovskaya ${ }^{1 *}$ \\ e-mail: volev10@mail.ru \\ Elena V. Novichonok ${ }^{2}$ \\ e-mail: enovichonok@inbox.ru \\ Tamara Yu. Dyachkova ${ }^{1}$ \\ e-mail: tdyachkova@mail.ru \\ Kira V. Morozova ${ }^{1}$ \\ e-mail: mkv25@bk.ru
}

\section{${ }^{1}$ Department of Botany and Plant Physiology, Petrozavodsk State University, Petrozavodsk, Russia}

${ }^{2}$ Karelian Research Centre RAS, Petrozavodsk, Russia

\section{* corresponding author}

Manuscript received: 04.03.2019 Review completed: 01.10.2019 Accepted for publication: 05.10.2019 Published online: 12.10.2019

\begin{abstract}
A B S T R A C T
By the bank of the Northern Dvina River for the first time Nymphoides peltata was registered in 2014. In the course of 4 years the area occupied by the population increased twofold and the projective cover degree of floating leaves also rose from $50 \%$ in 2014 to $100 \%$ with a considerable overlap of leaf blades in 2018. Structural-functional adaptations (high values of SLA and leaf thickness) are aimed at the acceleration of photosynthesis and growth. The analysis of the rapid light curves of chlorophyll fluorescence demonstrated that the species is well-adapted to the medium range of light values $\left(400-600 \mu \mathrm{mol} \mathrm{m}^{-2} \mathrm{~s}^{-1}\right)$. The optimal values of the maximum photochemical quantum yield of PS II ( $\mathrm{Fv} / \mathrm{Fm}$ $=0.81$ ) are indicative of the absence of stress conditions. Our data indicate that Nymphoides peltata is well-adapted to the environment in the studied habitat, have the high capacity for extending over a new territory and demonstrates signs of an invasive species.
\end{abstract}

Ke y w o r d s : aquatic plants, adaptation, chlorophyll fluorescence, invasive species, leaf anatomy, SLA

\section{P E 3 Ю M E}

Марковская Е.Ф., Новичонок Е.В., Аьячкова Т.Ю., Морозова К.В. Nymphoides peltata (S.G. Gmel.) O. Kuntze на границе ареала: экомогофизиологические особенности. Впервые на берегу реки Северная Авина вил Nymphoides peltata был зарегистрирован в 2014 году. За 4 года площадь популяции уве иичилась в Ава раза, степень проективного покрытия плавающих листьев выросла с 50 \% (в 2014 году) до 100 \% со значительным перекрытием Аистовых пластинок (в 2018 гоАу). Выявлены структурно-функциональные адаптации (высокие значения SLA и толщины миста), которые направлены на ускорение скорости фотосинтеза и роста. Анализ быстрых световых кривых флуоресценции хлорофилма показал, что вил хорошо аАаптирован к среднему диапазону значений освещенности (400-600 мкмоль $\left.\mathrm{M}^{-2} \mathrm{c}^{-1}\right)$. Оптимальные значения максимального фотохимического квантового выхода фотосистемы II (Fv/ Fm = 0.81) свидетельствуют об отсутствии напряженных условий. Наши данные показывают, что Nymphoides peltata хорошо аАаптирован к окружающей среде в изучаемом местообитании, обладает высокой способностью распространяться на новую территорию и Аемонстрирует признаки инвазивного виАа.

КАючевые слова: водные растения, адаптация, флуоресценция хлорофилма, инвазивные виды, анатомия Аиста, удельная площадь Аиста
Nymphoides peltata (S.G. Gmel.) O. Kuntze - is a plurizonal circumpolar species, its geographical range being in the temperate zone of Eurasia (Li et al. 2011, Săndulescu et al. 2016). This species has also been observed in North America since the late 19th century and in New Zealand since the late 20th century (Champion \& Clayton 2003, Darbyshire \& Francis 2008). In the territory of Russia, the species occurs to the north-east of the Northern Dvina River and also along the upper and lower course of the Vychegda River (Ivanina et al. 1977). In a number of regions in Russia this species is subject to protection as an rare species or species on the brink of extinction and is enlisted in the Red Books (Shchepovskih 1995, Fedorovskih 2003, Horuzhik 2005, Chernyagina 2007, Rozenberg 2007).
Despite the fact that in the majority of its habitats $N$. peltata is a rare species and is subject to protection, sometimes it is often considered to be a quickly proliferating invasive species (Les \& Mehrhoff 1999, Săndulescu et al. 2016). The rapid proliferation of this species is achieved due to its well-defined capability for vegetative propagation and clonogenic growth (Velde et al. 1979, Velde \& Heijden 1981, Brock et al. 1983, Larson 2007). Previously it was shown that vegetative propagation is the main means of reproduction in invasive populations of $N$. peltata in the territory of Sweden (Larson 2007). Being an invasive species and having a high capability for covering large areas of water surfaces, $N$. peltata can cause a reduction in the biodiversity of indigenous communities, have a negative impact on tourism and 
transport, and reduce the recreational functions of water bodies (Larson 2007, Walther et al. 2009, Săndulescu et al. 2016). At the present time, the problem of species invasion is aggravated due to the new challenges of global warming and climate changing (Walther et al. 2009, Bradley et al. 2010).

The description of species communities with the predominance of this species has been given in the studies of a number of researchers from Western Europe, mostly from Romania (Krausch 1965, Nedelcu 1969). In Russia, there have also been scientific works devoted to the studies of the general architectural model of these plants (Lednev 2015), as well as the anatomical and morphological structure of their vegetative organs (Markovskaya et al. 2015, 2018). However, there are very few data on the physiological peculiarities of $N$. peltata. Previously it was shown that $N$. peltata has a high capacity for adaptation to the changing environment (including land environment) due to the changes in its anatomical and morphological features (Li et al. 2011).

In the area of the present study (the Arkhangelsk Region), $N$. peltata occurs at the northern limit of its geographical range and therefore is considered to be vulnerable. In view of this, it is highly relevant to study its adaptive capacity, as well as its morphological, anatomical and physiological peculiarities under the present habitat conditions. However, in recent years there has been an active proliferation of $N$. peltata along the banks of the Northern Dvina River, which also calls for the need to study the cause of this phenomenon and make forecasts as to its further proliferation.

\section{MATERIAL AND METHODS \\ Subject and study area}

The subject of the study is Nymphoides peltata (S.G. Gmel.) O. Kuntze. - a perennial herbaceous aquatic plant of the family Menyanthaceae. N. peltata populations, as a rule, occur in water bodies with quiescent water, such as ponds, lakes and the slowly flowing waters of crescentic lakes (Gubanov et al. 2004, Wang et al. 2004).

N. peltata as a rare adventitious species was first registered in 2014 on the left bank of the Northern Dvina River in the village of Anfimovskaya (the Archangelsk region) $\left(62^{\circ} 2^{\prime} \mathrm{N} 45^{\circ} 4^{\prime} \mathrm{E}\right)$, which gave reason to believe that this species occurrence at this location is a floristic find.

The study was conducted in the area of taiga. The study region is located in an excessive moistening zone - the annual precipitation is $700 \mathrm{~mm}$. Throughout the year, precipitation varies considerably. During the cold season (November-March), the precipitation is $250 \mathrm{~mm}$, during the warm season (April-October), it can reach $450 \mathrm{~mm}$. The mean annual temperature is $1^{\circ} \mathrm{C}$. The average monthly temperature ranges from $-13.5^{\circ} \mathrm{C}$ in January to $+10^{\circ} \mathrm{C}$ in July. The duration of the freeze-free period is about 100 days (Fedorov et al. 1976, Tarkhanov et al. 2004).

The biometrical studies were conducted in the growing seasons of 2014, 2017 and 2018. The anatomical and physiological studies were carried out in the period of active vegetation (end of July-August) of 2018.

\section{Biometric measurements}

In order to take biometric measurements, each year during the study period, 100 of well-developed floating leaves were sampled. For the measurement of the leaf area, the leaves were scanned. Leaf area was measured using ImageJ software. The specific leaf area (SLA) was calculated as a leaf area to dry leaf mass ratio. For its estimation, leaf with a known area were dried until oven-dry at $80^{\circ} \mathrm{C}$ and then weighed.

\section{Anatomical measurements}

Ten floating leaves were sampled (with an area of 40 $55 \mathrm{~cm}^{2}$ ) and fixed using $70 \%$ ethanol. The leaf anatomical structure was studied in the cross-section and longitudinal section cuts made with a razor blade by hand with the help of a light microscope (Zeizz, Germany). The biometric measurements of the anatomical features were taken using an eyepiece micrometer WF10X/22 mm in 50 replicates. To study the types of stomata, their number and size, longitudinal paradermal sections of leaves were performed. The number of chloroplasts was calculated in suspension after preliminary cell maceration (Mokronosov \& Borzenkova 1978) in 50 cells of the palisade and the spongy mesophyll of leaves. The stomatal area was calculated using the formula:

$$
S=\pi \times D \times \frac{L}{4}
$$

where $D$ - stomatal length, $L$ - stomatal width. The volume of cells was calculated using the linear dimensions of cells ( $L$ - length, $D$ - width) (Mokronosov \& Borzenkova 1978) with the correction factor $k$ (Tselniker 1978):

$$
V=\frac{1}{4} \pi \times D \times L \times k, k=0.38+0.117 \times \frac{L}{D}
$$

The volume of cells corresponding to one chloroplast, or the cellular chloroplast volume (CCV) was determined using the formula:

$$
C C V=\frac{\text { Vcell }}{\text { Nch }}
$$

where $V$ cell - cell volume, $N c h-$ number of chloroplasts per cell.

\section{Determination of chlorophyll fluorescence}

To measure the chlorophyll fluorescence the fluorimeter with a pulse-modulated light source (JUNIOR-PAM, Walz, Germany) was used. The chlorophyll fluorescence parameters were measured after 30-minute dark adaptation. The following chlorophyll fluorescence parameters were determined: basic fluorescence yield (F0), maximal fluorescence yield $(\mathrm{Fm})$ and variable fluorescence yield $(\mathrm{Fv})$ (the saturating impulse PPFD being $10000 \mu \mathrm{mol} \mathrm{m}^{-2} \mathrm{sec}^{-1}$ ), the maximum photochemical quantum yield of PS II ( Fv/ Fm). The rapid light curves (RLCs) were obtained using the WinControl software. The fluorescence yield $(\mathrm{F})$, the maximum fluorescence yield of a light-adapted leaf ( $\left.F^{\prime} m\right)$, the relative electron transport rate (ETR), the effective quantum yield of PSII (Y(II)), the coefficients of photochemical (qP) and non-photochemical fluorescence quenching 
(NPQ) were registered at PAR being 66, 90, 125, 190, 285, 420, 625 and $820 \mu \mathrm{mol} \mathrm{m} \mathrm{m}^{-1}$. Based on PAR-ETR curves minimum saturating irradiance (Ek) was determined.

\section{RESULTS}

The area populated by the plants includes territories with a depth ranging from 30 to $70 \mathrm{~cm}$. The area covered by the population $N$. peltata in 2014 was approximately $20 \mathrm{~m}^{2}$, the projective cover degree of floating leaves accounted for about $50 \%$, at times coming up to $80 \%$. In 2017 , the area covered by the population had increased and totaled to 30$40 \mathrm{~m}^{2}$, the projective cover degree at some points reaching $100 \%$, with a considerable overlap of leaf blades. In 2017, the leaf area in $1 \mathrm{~m}^{2}$ was $1.4 \mathrm{~m}^{2}$, in 2018 it was $1.8 \mathrm{~m}^{2}$.

All the samples of floating leaves were divided into several groups depending on their leaf blade area: group I leaves with an area $5-15 \mathrm{~cm}^{2}$, group II $-20-35 \mathrm{~cm}^{2}$, group III - 40-55 $\mathrm{cm}^{2}$ (see Table 1). In 2018, as compared to 2017, there was a decrease in the number of leaves with the smallest area (group I) and an increase in the number of large leaves (group III), whereas the percentage of leaves with medium values of leaf blade area (group II) remains the same and accounts for about $60 \%$. The SLA values varied over a wide range. In 2017, they were similar in leaves of all the three groups. In 2018, the SLA values were similar in leaves of groups II and III; the highest SLA values were observed in leaves of group I. In 2018, the SLA values for all leaves increased almost twofold (Table 1).

Anatomical measurement showed that leaves of $N$. eltata belong to the dorzoventral type. The palisade mesophyll is located on the adaxial side, the spongy mesophyll - on the abaxial side. The average leaf blade thickness is $1046 \mu \mathrm{m}$ (Table 2). On the top side of leaves, numerous anomocytic stomata were identified. The lower epidermis is characterized by the absence of stomata and the formation of hydropotes. The hydropotes are subcircular groups of smaller cells (from 30 to 150 in number), through which water with dissolved mineral salts penetrates into the leaf blade.

The cells of palisade mesophyll are arranged densely, in 2 rows. The cells of spongy parenchyma account for a large portion of the leaf blade, they are arranged loosely, between them large intercellular spaces are formed and the cell volume of this assimilative tissue is twice the cell volume of palisade parenchyma. In the cells of palisade mesophyll, the number of chloroplasts is almost twice as high as that in the cells of spongy mesophyll. At the same time, the mean cell volume of one particular chloroplast in the cells of spongy mesophyll is three times as high as that in the cells of palisade parenchyma (Table 2).

The study of the chlorophyll fluorescence parameters showed that the $\mathrm{Fv} / \mathrm{Fm}$ ratio $0.81 \pm 0.014$. The study of the RLC revealed a relatively gradual decrease in Fm' with increasing PAR (Fig. 1). The reduction of Fm' between SF1 (saturation flash 1) and SF9 equaled $44.8 \%$. F rises sharply with PAR increasing up to $66 \mu \mathrm{mol}$ photons $\mathrm{m}^{-2}$ $\mathrm{s}^{-1}$, and then it gradually decreases. The rise in PAR leads to a considerable decrease in $\mathrm{Y}(\mathrm{II})$ and $\mathrm{qP}$ and an increase in NPQ and ETR. Moreover, ETR does not go down after saturation $\left(\mathrm{Ek}=382.3 \mu \mathrm{mol}\right.$ photons $\left.\mathrm{m}^{-2} \mathrm{~s}^{-1}\right)$ (Fig. 1).

\section{DISCUSSION}

The population of $N$. peltata was first registered in the studied area in 2014 and is still at the early stages of formation. In the course of four-year observations (from 2014 to 2018), the area occupied by the population increased twofold. The territory populated by the plants includes depths ranging between 30 and $70 \mathrm{~cm}$, their further expansion over greater depths is limited. The increase in the population area is achieved through the propagation of the species along the course of the river. Apart from that,
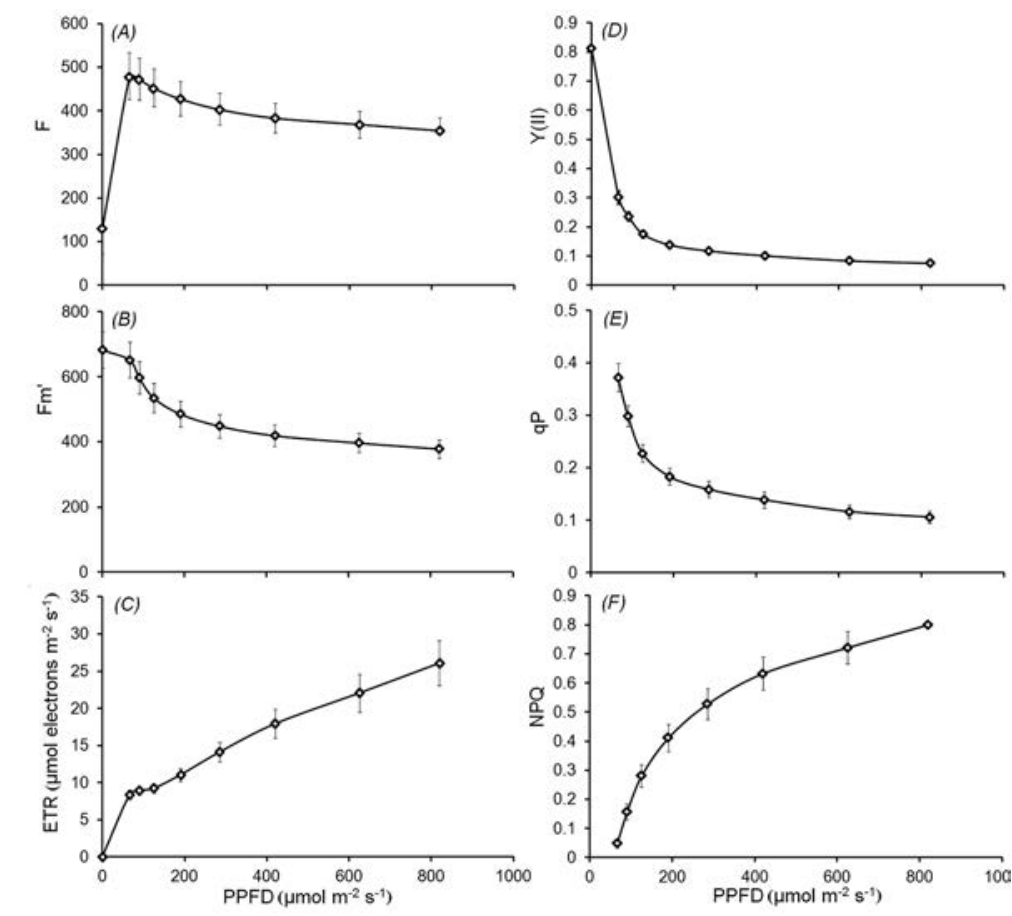

Figure 1 Parameters of rapid light curves: (A) the fluorescence yield (F), (B) the maximum fluorescence yield of a light-adapted leaf $\left(F^{\prime} m\right),(C)$ the quantum yield of PSII (Y(II)), (D) the coefficients of photochemical quenching (qP), (E) the coefficients of non-photochemical fluorescence quenching (NPQ), (F) the relative electron transport rate (ETR), as a function of PPFD

Table 1. Percentage and specific leaf area (SLA) in Nymphoides peltata leaves of different groups.

\begin{tabular}{|c|c|c|c|c|c|c|}
\hline \multirow[t]{2}{*}{ Year } & \multicolumn{2}{|c|}{ Group of leaves I $\left(S=5-15 \mathrm{~cm}^{2}\right)$} & \multicolumn{2}{|c|}{ Group of leaves II $\left(\mathrm{S}=16-35 \mathrm{~cm}^{2}\right)$} & \multicolumn{2}{|c|}{ Group of leaves III $\left(\mathrm{S}=36-55 \mathrm{~cm}^{2}\right)$} \\
\hline & $\begin{array}{l}\text { Percentage of } \\
\text { total leaves }\end{array}$ & SLA, $\mathrm{cm}^{2} \mathrm{~g}^{-1}$ & $\begin{array}{l}\text { Percentage of } \\
\text { total leaves }\end{array}$ & SLA, $\mathrm{cm}^{2} \mathrm{~g}^{-1}$ & $\begin{array}{l}\text { Percentage of } \\
\text { total leaves }\end{array}$ & SLA, $\mathrm{cm}^{2} \mathrm{~g}^{-1}$ \\
\hline 2017 & 30 & $100-180$ & 60 & $120-200$ & 10 & $120-180$ \\
\hline 2018 & 10 & $270-460$ & 60 & $200-370$ & 30 & $220-370$ \\
\hline
\end{tabular}


Table 2. Quantitative traits of leaf anatomy of Nymphoides peltata.

\begin{tabular}{|c|c|c|}
\hline Traits & & $\begin{array}{l}\text { Mean } \pm \text { standard } \\
\text { error of the mean }\end{array}$ \\
\hline Leaf thickness, $\mu \mathrm{m}$ & & $1046 \pm 12$ \\
\hline Number of stomata on the adaxial side, pieces per $\mathrm{mm}^{2}$ & & $440 \pm 9$ \\
\hline Stomata area, $\mu m^{2}$ & & $323.1 \pm 11.4$ \\
\hline Cell volume, $\mu \mathrm{m}^{3} \times 10^{3}$ & palisade mesophyll & $\begin{array}{l}23.0 \pm 1.4 \\
401+37\end{array}$ \\
\hline Amount of chloroplast, pieces & $\begin{array}{l}\text { palisade mesophyll } \\
\text { spongy mesophyll }\end{array}$ & $\begin{array}{l}48.5 \pm 0.8 \\
27.1 \pm 0.6\end{array}$ \\
\hline Cellular chloroplast volume, $\mu \mathrm{m}^{3}$ & $\begin{array}{l}\text { palisade mesophyll } \\
\text { spongy mesophyll }\end{array}$ & $\begin{array}{l}480.1 \pm 31.7 \\
1525.6 \pm 144.0\end{array}$ \\
\hline
\end{tabular}

the species population is also adopting the water surface through the increase in leaf density: in 2014 the projective cover degree of floating leaves amounted to about $50 \%$, sometimes coming up to $80 \%$, in 2017 it reached $100 \%$ with a considerable overlap of leaf blades.

In 2018, SLA value for all leaves increased almost twofold, which is indirectly indicative of an increase in photosynthetic rate and, consequently, the biological productivity of the plant. The dependence between SLA values and the amount of absorbed light is well established, as well as that between photosynthetic rate per unit of dry mass and relative growth rate (Poorter \& Der Werf 1998, Evans \& Poorter 2001, Leishman et al. 2007). Previously it was shown that SLA is one of the key parameters that allow for the differentiation of species according to the strategy of resource acquisition and utilization (Leishman et al. 2007). High SLA values are characteristic of invasive species, they ensure their rapid growth and are beneficial in the setting of high resource availability. On the other hand, low SLA values are typical of plants growing in habitats with limited resources, in situations when the preservation of the acquired resources is top priority (Wilson et al. 1999, Leishman et al. 2007). The observed increase in SLA was associated with the strategy of quick growth and provides for a high capacity of $N$. peltata for expansion over a new territory and holding onto it (Leishman et al. 2007).

In 2018, as compared to 2017, an increase in the area of leaves was noted. There was also a reduction in the number of leaves with the smallest area (group I) and an increase in the number of large leaves (group III), whereas the percentage of leaves with meadium values (group II) remains the same and amounts to about $60 \%$. Such a sharp increase in the leaf area can be accounted for by the high adaptation to the environmental factors and the strategy of quick growth, as well as the climatic peculiarities observed in 2018. In 2018, as compared to 2017, the mean air temperature values were higher (Table 3 ). Moreover, higher than normal temperature values were occasionally reported in this region. For instance, the highest air temperature in July 2018 was $30.6^{\circ} \mathrm{C}$, in June it was $28.7^{\circ} \mathrm{C}$.

The conducted anatomical study showed that leaves of N. peltata have a typical structure, characteristic of floating leaves of hydrophytes (N. peltata in particular): high leaf thickness, clearly differentiating dorsoventral mesophyll, stomata located on the top surface of leaf and hydropodes located on its lower surface, well-developed aerenchyma
Table 3. Mean air temperature values $\left({ }^{\circ} \mathrm{C}\right)$ in 2017 and 2018 (according to rp5.ru, data for vil. Verkhnaya Toyma which located $22 \mathrm{~km}$ away from study area).

\begin{tabular}{lll}
\hline & 2017 & 2018 \\
\hline June & 12.0 & 13.0 \\
July & 18.1 & 19.2 \\
August & 16.2 & 15.5 \\
\hline
\end{tabular}

with a large amount of cells occupying a considerable proportion of the leaf blade (Ronzhina \& P'yankov 2001a, Mehrvarz \& Nodehi 2016). At the same time, certain peculiarities of the anatomical structure were also observed.

The study of the leaf blade thickness showed that, in the studied habitat, thick leaves are typical of $N$. peltata. By way of comparison, in $N$. peltata plants growing in Lake Liangzi (China) and studied in the course of an experiment conducted by Chinese scientists, the thickness of leaves was twice as low (Li et al. 2011). The leaf thickness of the N.peltata plants studied in our experiment was higher than the thickness typical of floating leaves of various aquatic plants (Croxdale 1979, Nielsen \& Sand-Jensen 1993, Ronzhina \& P'yankov 2001b). The increase in leaf thickness is expected to lead to a higher photosynthetic rate (Pattison et al. 1998, Niinemets 1999, Yamashita et al. 2002). Thick leaf blades with a well-developed aerenchyma enable plants to store $\mathrm{CO}_{2}$ released during breathing and photorespiration, which makes it possible for them to re-use this $\mathrm{CO}_{2}$ in the photosynthetic process. (Ronzhina \& P'yankov 2001b).

In the studied plants, the cells of palisade mesophyll were arranged in two rows. It has been noted in the literature that it is dorsoventral mesophyll with two to three layers of palisade tissue that is characteristic of floating leaves of hydrophytes growing under sufficient light conditions (Ronzhina \& P'yankov 2001b). At the same time, in N. peltata plants growing in more southern regions, three to four rows of columnar cells have been observed (Mehrvarz \& Nodehi 2016, Săndulescu et al. 2016). The reduction in the number of layers of palisade mesophyll in plants growing in the North, as compared to plants of more southern regions, can be associated with the different levels of light availability. The increase in the number of layers of palisade mesophyll is characteristic of leaves growing under high light conditions (Vogelmann 1993, Vogelmann \&Martin 1993). In this case, the additional layers of columnar cells, apart from facilitating $\mathrm{CO}_{2}$ exchange, also serve for optical 
purposes. They ensure a more equal distribution of light inside the leaf, which in the context of excessive light prevents photoinhibition and photodamage (Vogelmann 1993, Vogelmann \& Martin 1993).

The photochemical activity of the photosynthetic apparatus of $N$. peltata was of special interest. It was determined that in all leaves the $\mathrm{Fv} / \mathrm{Fm}$ was $0.81 \pm 0.014$, which is close to the optimal value of $\mathrm{Fv} / \mathrm{Fm}(0.83)$, and is illustrative of the optimal conditions under which this species is growing (Björkman \& Demming 1987). The findings are indicative of the presence of actively functioning systems which keep the photosynthetic activity of the photosynthetic apparatus at a high level. The decrease in Fm' (fluorescence during saturated impulse) between SF1 (saturation flash) and SF9 was relatively low and totaled to $44.8 \%$. This indicates the limited capability for non-photochemical energy dissipation (Ralph \& Gademann 2005) and is confirmed by the relatively low values of NPQ. For instance, at a level of PAR being $820 \mu \mathrm{mol}$ photons $\mathrm{m}^{-2} \mathrm{~s}^{-1}$, the values of NPQ were $0.80 \pm 0.26$ (Fig. 1).

The dependence between ETR and PAR is also indicative of the limited capability for energy dissipation (Fig. 3). The ETR does not go down after saturation (Ek $=382.3 \mu \mathrm{mol}$ photons $\left.\mathrm{m}^{-2} \mathrm{~s}^{-1}\right)$. These data suggest that even at the values of PAR exceeding the saturation point, no acceleration of its loss due to non-photochemical quenching is registered (White \& Critchley 1999). However, the observed low values of Ek can imply that in the setting of high light and limited capability for the dissipation of energy, the photodamage of the photosynthetic apparatus is likely to occur (White \& Critchley 1999). The analysis of the dependence between Y(II) and PAR demonstrated that with increasing PAR, Y(II) drops sharply due to the limited capacity for photochemical utilization of energy. This is also confirmed by the sharp rise in $\mathrm{F}$ with increasing PAR (Fig. 3) due to the closure of reactive centers.

The increase in PAR also resulted in the quick decrease in qP (Fig. 3). Such variations of $\mathrm{qP}$ were caused by the closure of reactive centers due to the light saturation (Goltsev et al. 2014). These data suggest that the photosynthetic apparatus of this species is well-adapted to the medium range of light

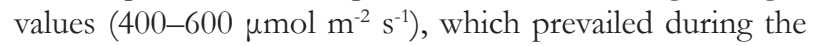
study period.

Summing up what has been said, the conducted study showed that N. peltata is well-adapted to the climatic conditions of North-West Russia. Its structural and physiological adaptations are aimed at the acceleration of photosynthetic processes (in the setting of high availability of resources) and growth respectively, which resulted in the rapid proliferation of the studied population. $N$. peltata demonstrates signs of an invasive species and in view of this, the propagation of N. peltata in the territory of North-West Russia must be closely monitored.

\section{ACKNOWLEDGEMENTS}

We thank Svetlana Filon for providing language support.

\section{LITERATURE CITED}

Björkman, O. \& B. Demming 1987. Photon yeld of $\mathrm{O}_{2}$ evolution and chlorophyll fluorescence characteristics at $77 \mathrm{~K}$ among vascular plants of diverse origins. Planta 170(4): 489-504.

Bradley, B.A., D.M. Blumenthal, D.S. Wilcove \& L.H. Ziska 2010. Predicting plant invasions in an era of global change. Trends in Ecology and Evolution 25(5):310-318.

Brock, T.C.M., G.H.P. Arts, I.L.M. Goossen \& A.H.M. Rutenfrans 1983. Structure and annual biomass production of Nymphoides peltata (Gmel.) O. Kuntze (Menyanthaceae). Aquatic Botany 17:167-188.

Champion, P.D. \& J.S. Clayton 2003. The evaluation and management of aquatic weeds in New Zealand. In: Plant invasions: Ecological threats and management solutions, (L. Child, J.H. Brock, G. Brundu, K. Prach, K. Pysěk, P.M. Wade, M. Williamson, eds), pp. 429-434, Backhuys.

Chernyagina, O.A. (ed.) 2007. Krasnaya kniga Kamchatki, Tom 2. Rasteniya, griby, termofil'nye mikroorganizmy. Petropavlovsk-Kamchatskii, Kamch. Pech. dvor, 341 pp. (in Russian). [Красная книга Камчатки. Т.2. Растения, грибы, термофильные микроорганизмы / отв. реА. Черня-

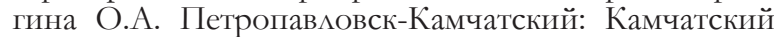
печатный Авор. 341 с.].

Croxdale, J.G. 1979 Salvinia leaves. II. Morphogenesis of the floating leaf. Canadian Journal of Botany 57(19):1951-1959.

Darbyshire, S.J. \& A. Francis 2008. The biology of invasive alien plants in Canada. 10. Nymphoides peltata (S.G. Gmel.) Kuntze. Canadian Journal of Plant Science 88:811-829.

Evans, J.R. \& H. Poorter 2001. Photosynthetic acclimation of plants to growth irradiance: the relative importance of specific leaf area and nitrogen partitioning in maximizing carbon gain. Plant, Cell and Environment 24 (8):755-767.

Fedorov, D.F., N.V. Razumihin \& A.G. Isachenko (eds) 1976. Atlas Arbangel'skoi oblasti. Glavnoe upravlenie geodezii i kartografii pri sovete ministrov SSSR, Moscow. $72 \mathrm{pp}$. (in Russian). [Атлас Архангельской об̆ласти. 1976/поА ред. Федорова А.Ф., Разумихина Н.В., Исаченко А.Г. М.: ГАавное управление геодезии и картографии при Совете министров СССР. 76 с.].

Fedorovskih, M.A. (ed.) 2003. Krasnaya kniga Khanty-Mansiyskogo avtonomnogo okruga: zhivotnye, rasteniya, griby. Pakrus, Ekaterinburg, 376 pp. (in Russian). [Красная книга Ханты-Мансийского автономного округа: Животные, растения, грибы 2003 / поА. реА. Федоровских М.А. Екатеринбург: Пакрус. 376 с.].

Goltsev, V.N., M.H. Kalaji, M.A. Kouzmanova \& S.I. Allakhverdiev 2014. Variable and delayed chlorophyll a fuorescence - basics and application in plant science. Institute of computer science, Moscow-Izshevsk, 220 pp. (in Russian). [Гольцев В.Н., Каладжи Х.М., Кузманова М.А., А^махверАиев С.И. 2014. Переменная и замедменная флуоресценция хлорофилла а - теоретические основы и практическое приложение в исследовании растений. Москва; Ижевск: Институт компьютерных исследований. 220 с.].

Horuzhik, L.I., L.M. Sushchenya, V.I. Parfenov et al. (eds) 2005 Krasnaya kniga Respubliki Belarus': Redkie i nakbodyashchiesya pod ngrozoy ischeznoveniya dikorastushchie vidy rasteniy. BelEhn, Minsk. 456 pp. (in Russian). [Красная книга Республики Беларусь: Редкие и находящиеся под угрозой исчезновения дикорастущие виды растений 2005 / под реА. Хоружик А.И. (предс.), Сущеня А.М., Парфенов В.И. и Ар. Минск: БелЭн. 456 с.].

Ivanina, L.I., T.P. Kobeleva, A.N. Lashchenkova, V.A. Martynenko, N.A. Minyaev, N.I. et al. 1977. Flora severo-vostoke evropeiskoj chaste SSSR, vol. 4. Nauka, 312 pp. (in Russian). 
[Иванина А.И., Кобелева Т.П., Аащенкова А.Н., Мартыненко В.А., Минаев Н.А. и Ар. 1977. ФАора северовостока европейской части СССР 1977. T. IV. А.: Наука. 312 с.].

Krausch, H.D. 1965. Vegetationskundliche Beobachtungen in Donaudelta. Limnologica 3:271-313.

Larson, D. 2007. Reproduction strategies in introduced Nymphoides peltata populations revealed by genetic markers. Aquatic Botany 86(4):402-406.

Lednev, S.A. 2015. Biomorphology and seasonal development of Nymphoides peltata (Gmel.) O. Kuntze. Byulleten Moskovskogo obshchestva ispytatelej prirody. Otdelenie biologiva 120(1):69-75 (in Russian). [ $\Lambda$ еннев С.А. Биоморфология и сезонное развитие Nymphoides peltata (Gmel.) O. Kuntze // Бюлметень Московского общества испытателей природы. ОтАеление Биология. 2015. T. 120, № 1. С. 69-75].

Leishman, M.R., T. Haslehurst, A. Ares \& Z. Baruch 2007. Leaf trait relationships of native and invasive plants: community- and global-scale comparisons. New Phytologist 176(3):635-643.

Les, D.H. \& L.J. Mehrhoff 1999. Introduction of nonindigenous aquatic vascular plants in southern New England: a historical perspective. Biological Invasions 1:281-300.

Li, Z., D. Yu \& J. Xu 2011. Adaptation to water level variation: Responses of a floating-leaved macrophyte Nymphoides peltata to terrestrial habitats. Annales de Limnologie - International Journal of Limnology 47:97-102.

Markovskaya, E.F., T.Yu. Dyachkova \& K.V. Morozova 2015. Anatomical and morphological features of Nymphoides peltata (S.G. Gmel.) O. Kuntze on the northwest edge of distribution range. Uchenye zapiski Petrozavodskogo Gosudarstvennogo Universiteta 2(147):17-22. (in Russian). [Марковская Е.Ф., Аьячкова Т.Ю., Морозова К.В. 2015. Анатомо-морфологические особенности Nymphoides peltata (S.G. Gmel.) O. Kuntze на северо-запаАной границе ареала // Ученые записки Петрозаводского государственного университета. №2 (147). C. 17-22].

Markovskaya, E.F., T.Yu. Dyachkova \& K.V. Morozova 2018. Nymphoides peltata (S.G. Gmel.) O. Kuntze (Menyanthaceae) on the boundary of distribution area: anatomical and morphological features. Hortus Botanicus 13: $291-$ 303 (in Russian). [Марковская Е.Ф., Аьячкова Т.Ю., Морозова K.B. 2018. Nymphoides peltata (S.G. Gmel.) O. Kuntze (Menyanthaceae) на границе apeasa: анатомо-морфологические особенности // Hortus Botanicus. №13. C. 291-303].

Mehrvarz, S.S. \& M.A. Nodehi 2016. A review of the genus Nymphoides (Menyanthaceae) in Iran. Phytotaxa 257(3): 261-270.

Mokronosov, A.T. \& R.A. Borzenkova 1978. A guide to quantitatine assessment of structure and functions of photosynthetic tissues and organs. Trudy po prikladnoy botanike, genetike i selek.tsii VNII rasteneevodstva 61(3): 119-133 (in Russian). [Мокроносов А.Т., Борзенкова Р.А. 1978. Методика количественной оценки структуры и функциональной активности фотосинтетических тканей и органов / / Труды по прикладной ботанике, генетике и селекции ВНИИ растенееводства. Т. 61, вып. 3. C. 119-133].

Nedelcu, G.A. 1969. Flora si vegetatia acvatică si palustră a cîtorva lacuri din Cîmpia Românăcu unele consideratii morfologice. Ed. Acad. R. S. R., Bucuresti, 232 pp.
Nielsen, S.L. \& K. Sand-Jensen 1993. Photosynthetic implications of heterophylly in Batrachium peltatum (Schrank) Presl. Aquatic Botany 44(4): 361-371.

Niinemets, Ü. 1999. Components of leaf dry mass per area - thickness and density - alter leaf photosynthetic capacity in reverse directions in woody plants. New Phytologist 144 (1): 35-47.

Pattison, R.R., G. Goldstein, A. Ares 1998. Growth, biomass allocation and photosynthesis of invasive and native Hawaiian rainforest species. Oecologia 117(4):449-459.

Poorter, H. \& A. Van Der Werf 1998. Is inherent variation in RGR determined by LAR at low irradiance and by NAR at high irradiance? A review of herbaceous species. In: Inherent variation in plant growth $(\mathrm{H}$. Lambers, $\mathrm{H}$. Poorter \& M.I. Van Vuuren, eds.), pp. 309-336, Backhuys, Leiden, the Netherlands.

Ralph, P.J. \& R. Gademann 2005. Rapid light curves: A powerful tool to assess photosynthetic activity. Aquatic Botany 82 (3): 222-237.

Ronzhina, D.A. \& V.I. P'yankov 2001a. Structure of the photosynthetic apparatus in leaves of freshwater hydrophytes: 2. Quantitative characterization of leaf mesophyll and the functional activity of leaves with different degrees of submersion. Russian Journal of Plant Physiology 48(6): $723-732$.

Ronzhina, D.A. \& V.I. P'yankov 2001b. Structure of the photosynthetic apparatus in leaves of freshwater hydrophytes: 1. General characteristics of the leaf mesophyll and a comparison with terrestrial plants. Russian Journal of Plant Physiology 48(5):567-575.

Rozenberg, G.S. (ed.). 2007. Krasnaya kniga Samarskoy oblasti. Tom 1. Redkie vidy rasteniy, lishaynikov, gribov. IehVB RAN, Tolyatti. 372 pp. (in Russian). [Красная книга Самарской области. Редкие виды растений, Аишайников и грибов 2007 / пол реА. Розенберг Г.С. Тольятти: ИЭВБ PAH. 372 c.].

Săndulescu, E.B., G.V. Scăețeanu, T. Şchiopu, N. Oltenacu, M.-M. Stavrescu-Bedivan 2016. Morpho-anatomy and adaptation to some Romanian aquatic environments of Nymphoides peltata (Gmel.) O. Kuntze (Asterales: Menyanthaceae). Scientific Papers. Series A. Agronomy 59:537-542.

Shchepovskih, A.I. (ed.). 1995. Krasnaya kniga Respubliki Tatarstan. Zhivotnye, rasteniya, griby. Priroda, Kazan. 454 pp. (in Russian). [Красная книга Республики Татарстан. Животные, растения, грибы 1995. ГА. реА. Щеповских А.И. Казань: Природа. 454 с.].

Tarhanov, S.N., N.A. Prozherina \& V.N. Konovalov 2004. Lesnye ebkosistemy bassejna Severnoj Dviny v usloviyah atmosfernogo zagryazneniya. UrO RAN, Ekaterinburg, 333 p. (in Russian). [Тарханов С.Н., Прожерина Н.А., Коновамов В.Н. 2004. Аесные экосистемы бассейна Северной Авины в условиях атмосферного загрязнения. Екатеринбург: УрО РАН. 333 с.].

Tselniker, Yu.L. 1978. Chloroplast replication and its meaning to photosynthesis. In: Mezostruktura i funktsionalnaya aketivnost fotosinteticheskogo apparata, pp. 31-45, Ural University Press, Sverdlovsk (in Russian). [Цельникер Ю. $\Lambda$. 1978. Репликация хлоропластов, ее регуляция и значение Аля фотосинтеза / / Мезоструктура и функциональная активность фотосинтетического аппарата. СверАловск: Уральский ун-т. С. 31-45].

Van der Velde, G. \& L.A. Van der Heijden 1981. The floral biology and seed production of Nymphoidespeltata (Gmel.) O. Kuntze (Menyanthaceae). Aquatic Botany 10: 261-293. 
Van der Velde, G., T.G. Giesen \& L.A. Van der Heijden 1979. Structure, biomass and seasonal changes in biomass of Nymphoides peltata (Gmel.) O. Kuntze (Menyanthaceae), a preliminary study. Aquatic Botany 7: 279-300.

Vogelmann, T.C. 1993. Plant tissue optics. Annual review of plant physiology and plant molecular biology 44:231-251.

Vogelmann, T.C. \& G. Martin 1993. The functional significance of palisade tissue: penetration of directional versus diffuse light. Plant, Cell and Environment 16(1):65-72.

Walther, G.-R., A. Roques, Ph.E. Hulme, M.T. Sykes, P. Pyšek et al. 2009. Alien species in a warmer world: risks and opportunities. Trends in Ecology and Evolution 24(12):686-693.
White, A.J. \& C. Critchley 1999. Rapid light curves: A new fluorescence method to assess the state of the photosynthetic apparatus. Photosynthesis Research 59 (1): $63-72$.

Wilson, P.J., K. Thompson \& J.G. Hodgson 1999. Specific leaf area and leaf dry matter content as alternative predictors of plant strategies. New Phytologist 143(1):155-162.

Yamashita, N., N. Koike \& A. Ishida 2002. Leaf ontogenetic dependence of light acclimation in invasive and native subtropical trees of different successional status. Plant, Cell and Environment 25(10):1341-1356. 